\title{
First data on habitat preference, diet and length-weight relationship of Gobius incognitus Kovačić \& Šanda, 2016 (Pisces: Gobiidae)
}

\author{
Francesco TIRALONGO $^{1,2^{*}}$, Giuseppina MESSINA ${ }^{1}$ and Bianca Maria LOMBARDO ${ }^{1}$ \\ ${ }^{1}$ Department of Biological, Geological and Environmental Sciences, University of Catania, \\ Catania, Italy
}

${ }^{2}$ Ente Fauna Marina Mediterranea, Avola, Italy

"Corresponding author: francesco.tiralongo@unict.it

In this work, we present first data on biological and ecological aspects of Gobius incognitus from specimens from the Ionian Sea (central Mediterranean Sea). In particular, we provided first data on habitat preference, diet and length-weight relationship of $\mathrm{G}$. incognitus on material with confirmed species identity. The species preferred "mixed bottom" (sand and rocks), where it reached relatively high abundances. The diet analysis showed that G. incognitus is a generalist and opportunistic feeder. However, small benthic crustaceans were the most important prey group. The mean total length of specimens was $6.72 \pm 1.85 \mathrm{~cm}$ and the growth was positive allometric.

Key words: Mediterranean Sea, goby, feeding habits, visual census, Gobius bucchichi, habitat preference

\section{INTRODUCTION}

Despite small benthic and cryptobenthic fish such as gobies and blennies are important components of marine ecosystems, these organisms are rarely studied and data on their habitat preferences are scarce and incomplete (KOVAČIĆ et al., 2012; TIRALONGO et al., 2016a). Several of these species are considered rare and are known from a few published records (PATZNER, 1999a; TIRALONGO et al., 2013; TIRALONGO \& BALDACCONI, 2015; TIRALONGO \& PAGANO, 2015; TIRALONGO et al., 2016b; ORDINES et al., 2019; TIRALONGO et al., 2019).

The Gobiidae, with more than 1900 valid species (FRICKE et al., 2020), is one of the largest fish families (NELSON et al., 2016). This is also valid for the Mediterranean Sea, where, with more than 70 species, Gobiidae is the most specious fish family (PATZNER, 2019). However, data about biology and ecology for most of the species are scarce and dated, and only in relatively recent years some studies have deepened some ecological aspects of some species (HERLER \& PATZNER, 2005; KOVAČIĆ \& PIJEVAC, 2008).

Gobius incognitus Kovačić \& Šanda, 2016 is a recently described species from the Mediterranean Sea (KOVAČIĆ \& ŠANDA, 2016). This new species was separated from the very similar Gobius bucchichi Steindachner, 1870 by morphological, meristic and molecular traits. Gobius incognitus has a wider distribution in 
the Mediterranean Sea, having been observed from the western to the eastern part of the basin; while, the presence of the redescribed G. bucchichi is actually only reported from the eastern part of the Adriatic Sea and from the northern Ionian Sea (Albania) (KOVAČIĆ \& ŠANDA, 2016). In consideration of this, most of the previous studies on G. bucchichi probably concern G. incognitus.

Gobius incognitus is a small medium-sized goby (maximum total length of about $8-10 \mathrm{~cm}$ ) (PATZNER, 2019) that inhabits shallow coastal waters, from just below the surface down to 12 $\mathrm{m}$ in depth. It is reported to occur on several different substrates, such as sandy bottoms covered by algae or sea grasses, or by gravel, cobbles, boulders and bedrock. Gobius bucchichi was observed associated with the sea anemone Anemonia viridis (Forsskål, 1775), and seeks protection in the tentacles of the sea anemone when it feels threatened (ABEL, 1960). However, on the basis of the study of KOVAČIĆ \& ŠANDA (2016), this behaviour could instead concern $G$. incognitus. This is also valid for the study of PATZNER (1999b) that described the association between juveniles of G. bucchichi and sea urchins, Paracentrotus lividus (Lamarck, 1816) in particular. The fish, when feels threatened, finds protection by hiding under sea urchins.

The body of $G$. incognitus is quite slender and moderately compressed posteriorly. Head relatively large and depressed. Snout oblique and longer than eye with anterior nostril short, tubular with tentacle. Eyes are dorsolateral with a narrow interorbital space. Jaws with caniniform teeth arranged in series. Fins: D1: VI; D2: I/13-14; A: I/12-13, P: 18-20. Color in life: background color of the body dark dorsally (greenish/grey to pale grey) and light ventrally (pale grey). Rows of dark spots, forming broken longitudinal lines, are present on body; midlateral longitudinal row with 8-9 larger dark spots, extending from the pectoral axilla to the caudal fin base. Unlike G. bucchichi, in which on the cheeks there are only two rows of elongated dots, without other dots between them at the middle of the cheek itself, in $G$. incognitus the dots on cheeks are irregularly scattered or, if arranged in rows, additional dots or a third row of dots is present across the middle of the cheek, between the lower row, starting anteriorly at the angle of mouth, and the upper row, that touches ventral margin of the eye (KOVAČIĆ \& ŠANDA, 2016).

Some data concerning biology and ecology of G. bucchichi were reported from the Gulf of Cadiz (approximatively the westernmost range of the species) and western Mediterranean Sea (SASAL et al., 1996a; SASAL et al., 1996b; BOUCHEREAU \& GUELORGET, 1999; PATZNER, 1999b; COMPAIRE et al., 2016). However, considering the geographic extent of the study areas, they most likely refer to G. incognitus (KOVAČIĆ \& ŠANDA, 2016).

In this work, we investigated biological and ecological aspects of $G$. incognitus, providing first data certainly attributable to this species, such as habitat preference, diet composition and length-weight relationship.

\section{MATERIAL AND METHODS}

The study area was located in the southeastern Sicily, Ionian Sea (central Mediterranean Sea). Fish-habitat associations were investigated by visual census methods in all the main shallow waters habitat types of the area. All these habitats were located within 3 kilometers of the coastline of Avola (Fig. 1). Visual census was conducted from June to September 2019, twice per month, with an interval of about 15 days and a total of survey time of 960 minutes distributed in 32 transects of 30 minutes each. In the same period, total of 96 specimens were collected with hand net for biological investigation. They were caught at different nearby locations, in order to not alter fish abundance during visual census surveys.

Habitat preference was investigated by visual census methods using horizontal transects at $1 \mathrm{~m}$ depth. The strip transects used were 30 $\mathrm{m}$ long and 1 meter wide $(50 \mathrm{~cm}$ to the right and $50 \mathrm{~cm}$ to the left of the transect tape), for a total of $30 \mathrm{~m}^{2}$. Fish count was performed in snorkeling at the speed of $1 \mathrm{~m} \mathrm{x} \mathrm{min}^{-1}$ and in the morning between 09:00 and 13:00. At each survey, we took into account only the presence 


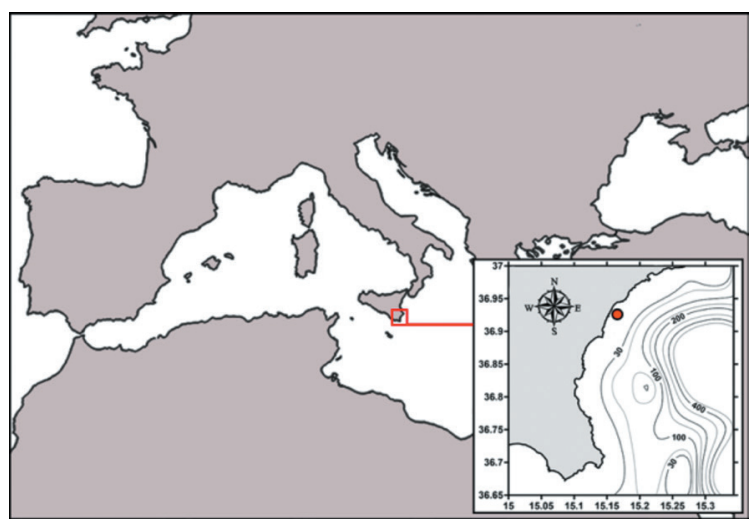

Fig. 1. The red square indicates the southeastern Sicily (zoomed in the inset). The study area, located in the Ionian Sea, is indicated with a red circle in the inset.

and abundance of $G$. incognitus and the presence of other goby species. The fishes did not appear to be particularly disturbed by the transect and by the diver's presence. Each leaded transect was laid at 1 meter depth twice a month for each of the following four selected habitat types: $p s$ (pebbles and sand), $r v$ (rock with vegetation), $s$ (sand), and $s r$ (sand and rocks). In $p s$, the sandy bottom was irregularly covered for about $50 \%$ by small and medium-sized pebbles with sizes between $10-40 \mathrm{~cm}$. In $r v$, the bottom was almost entirely rocky with algal vegetation; isolated specimens of $A$. viridis were scattered among rocks, often surrounded by a small (about 15-20 $\mathrm{cm}$ in diameter) area of gravels and coarse sand. In $s$, the bottom was entirely sandy. In $s r$, the sandy bottom was irregularly covered by big rocks.

After sampling, fishes were anesthetized and killed in ice-water and measured in total length (TL) and standard length (SL) to the nearest millimeter, and weighted to the nearest $0.01 \mathrm{~g}$. The stomach was removed from each fish and its content analyzed. All prey items in the stomachs were counted, washed in clean seawater and dried with blotter paper, identified under dissecting microscope to the lowest taxonomic level possible and weighed to the nearest $0.001 \mathrm{~g}$. Unidentifiable digested material was indicated as "digested".

Weight, total length and standard length measures of fish specimens were used for the length-weight relationship following the formula: $\mathrm{W}=\mathrm{aL}^{\mathrm{b}}$, where $\mathrm{W}$ is the weight in grams $(\mathrm{g}), \mathrm{L}$ is the total length in centimeters (cm), $a$ is the intercept and b is the slope of the regression curve.

The frequency of occurrence $(\% \mathrm{~F})$, percentage weight $(\% \mathrm{~W})$, percentage abundance $(\% \mathrm{~N})$ and the Index of Relative Importance (\%IRI) were calculated for each prey category in the diet (HYSLOP, 1980; CARRASSÒN et al., 1997). The vacuity index (percentage of empty stomachs) was also calculated (HUREAU, 1970).

According to the value of their percentage abundance $(\% \mathrm{~N})$, preys were grouped into three categories (N'DA, 1992): dominant ( $>50 \%)$, secondary $(10 \%<\mathrm{N}<50 \%)$ and accidental $(\mathrm{N}<10 \%)$.

The feeding strategy of $G$. incognitus was visually examined using a modified version of the COSTELLO (1990) graph by plotting the preyspecific biomass $(\mathrm{P} i)$ against their frequency of occurrence $(\% \mathrm{~F})$ (AMUNDSEN et al., 1996):

$$
\mathrm{P} i=\frac{\mathrm{SW} i}{\mathrm{SW} t_{i}} \times 100
$$

where $\mathrm{P} i$ is the prey-specific biomass of prey $i, \mathrm{SW}_{i}$ the stomach content biomass of prey $i$, and $\mathrm{SW} t_{i}$ the total stomach content biomass in those predators with prey $i$ in the stomach.

Standardized Levins' index $(\mathrm{B} i)$ was used to evaluate the breadth of the diet (KREBS, 1989):

$$
\begin{aligned}
& \mathrm{B}=\frac{1}{\sum p_{j}^{2}} \\
& \mathrm{~B} i=\frac{\mathrm{B}-1}{\mathrm{~B}_{\text {max }}-1}
\end{aligned}
$$

where $p_{j}$ is the relative frequency specimens in the $\mathrm{j}^{\text {th }}$ prey item and $\mathrm{B}_{\max }$ is the total number of prey item categories found. $\mathrm{B} i$ is comprised between 0 (narrow trophic niche) and 1 (wide trophic niche); if $\mathrm{B} i<0.40$ the species is considered a specialist, if $0.40<\mathrm{B} i<0.60$ is considered an "intermediate", if $\mathrm{B} i>0.60$ is considered a generalist (NOVAKOWSKI et al., 2008).

To evaluate whether the number of the analyzed stomachs was sufficient to describe the diet of the species, a cumulative prey curve (BROWN et al., 2012; TIRALONGO et al., 2018) 
was computed with R Studio (R CORE TEAM, 2019) using the package "vegan". The estimated number of prey groups and associated SD were plotted against the cumulative number of individuals whose stomach was examined.

Habitat preference was tested using one-way ANOVA followed by Tukey's post-hoc test, in order to highlight differences in fish abundance between habitat types.

\section{RESULTS}

The ANOVA results $(\mathrm{p}<0.01)$ and Tukey pairwise post-hoc comparisons (Fig. 2) showed a clear difference in abundance of specimens between all the four habitat types investigated (Table 1). The highest number of specimens was observed in "sand and rocks" (mean abundance $=18.12 \pm 3.40$; mean density $=0.60$ \pm 0.11 specimens $/ \mathrm{m}^{2}$ ), followed by "pebbles and sand" (mean abundance $=11.12 \pm 3.52$; mean density $=0.37 \pm 0.12$ specimens $\left./ \mathrm{m}^{2}\right)$, "rock with vegetation" (mean abundance $=7.13 \pm 1.81$; mean density $=0.24 \pm 0.06$ specimens $/ \mathrm{m}^{2}$ ) and "sand" (no observations). Other recorded species of gobies were Gobius cobitis Pallas, 1814 and Gobius paganellus Linnaeus, 1758 in sr, ps and $r v$ and Pomatoschistus marmoratus (Risso, 1810) in s. No specimens of G. bucchichi were recorded in the study area.

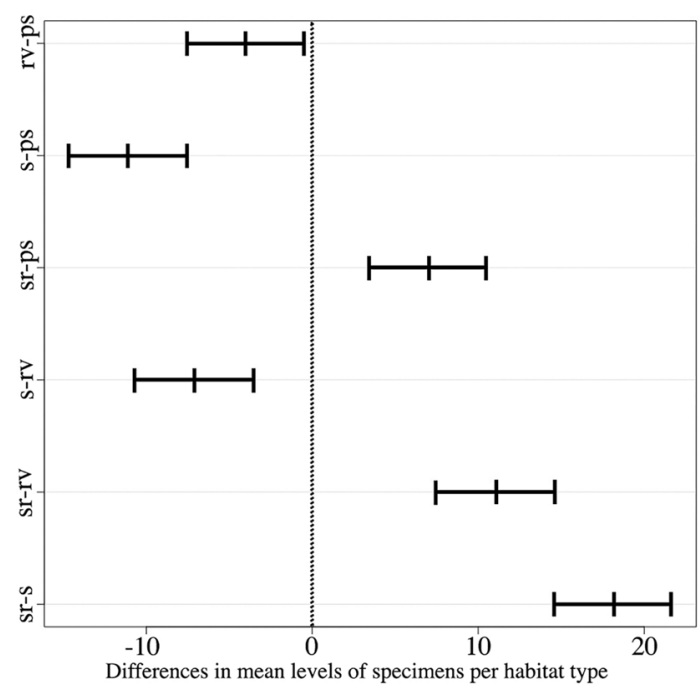

Fig. 2. Tukey results for pairwise comparisons of the mean level of number of specimens per habitat type
Table 1. Number of specimens (abundance) and specimens/ $m^{2}$ (density) per habitat type of $\mathrm{G}$. incognitus; $p s=$ pebbles and sand; $r v=$ rock with vegetation; $s=$ sand; $s r=$ sand and rocks; n.o. $=$ no observations

\begin{tabular}{|c|c|c|c|c|}
\hline \multicolumn{5}{|c|}{ Number of specimens } \\
\hline Habitat type & Min. & Max. & Mean & SD \\
\hline ps & 6 & 17 & 11.12 & 3.52 \\
\hline rv & 5 & 10 & 7.13 & 1.81 \\
\hline s & n.o. & n.o. & n.o. & n.o. \\
\hline sr & 15 & 25 & 18.12 & 3.40 \\
\hline \multicolumn{5}{|c|}{ Specimens/m ${ }^{2}$} \\
\hline Habitat type & Min. & Max. & Mean & SD \\
\hline ps & 0.20 & 0.57 & 0.37 & 0.12 \\
\hline rv & 0.17 & 0.33 & 0.24 & 0.06 \\
\hline s & n.o. & n.o. & n.o. & n.o. \\
\hline sr & 0.50 & 0.83 & 0.60 & 0.11 \\
\hline
\end{tabular}

The total length-weight relationship $(\mathrm{N}=$ 96) is graphically represented in Fig. 3 and shows a positive allometric growth $(b=3.088)$. The mean total length was $6.72 \pm 1.85 \mathrm{~cm}$ and ranged from 3 to $10.3 \mathrm{~cm}$ (Fig. 4); the mean standard length was $5.56 \pm 1.54 \mathrm{~cm}$ and ranged $2.5-8.5 \mathrm{~cm}$; the mean weight was $3.62 \pm 2.73 \mathrm{~g}$ and ranged $0.18-10.12 \mathrm{~g}$ (Table 2).

The analysis of the cumulative prey curve indicated that $\sim 50$ stomachs are necessary to obtain a sufficient sample to describe the overall diet of $G$. incognitus (Fig. 5). Out of the total number of 96 specimens analyzed, 84 (size range 3.6-10.3 cm TL) had prey in their stomach (vacuity index of $87.5 \%$ ). The stomach content analysis revealed that $G$. incognitus mainly feeds on small benthic crustaceans, but also molluscs (Fig. 6 \& Table 3).

However, nopreference was observed between prey species: the value of the standardized Levins' index (Bi) was 0.83 (digested category was included in the analysis), indicating a wide trophic niche (generalist species), as was also underlined by the plotted results of the preyspecific $(\mathrm{P} i)$ biomass of the food items against the frequency of occurrence $(\% \mathrm{~F})$ (Fig. 7). Furthermore, from a total of 14 identified food items, no dominant $(\% \mathrm{~N}>50)$ ones were found, 
Table 2. Main statistics on length and weight of $\mathrm{G}$ incognitus; $T L=$ total length; $S L=$ standard length; $W=$ weight

\begin{tabular}{|c|c|c|c|c|}
\hline \multicolumn{5}{|c|}{ Sizes and weight of Gobius incognitus } \\
\hline & Min. & Max. & Mean & SD \\
\hline TL (cm) & 3 & 10.3 & 6.72 & 1.85 \\
\hline SL (cm) & 2.5 & 8.5 & 5.56 & 1.54 \\
\hline W (g) & 0.18 & 10.12 & 3.62 & 2.73 \\
\hline
\end{tabular}
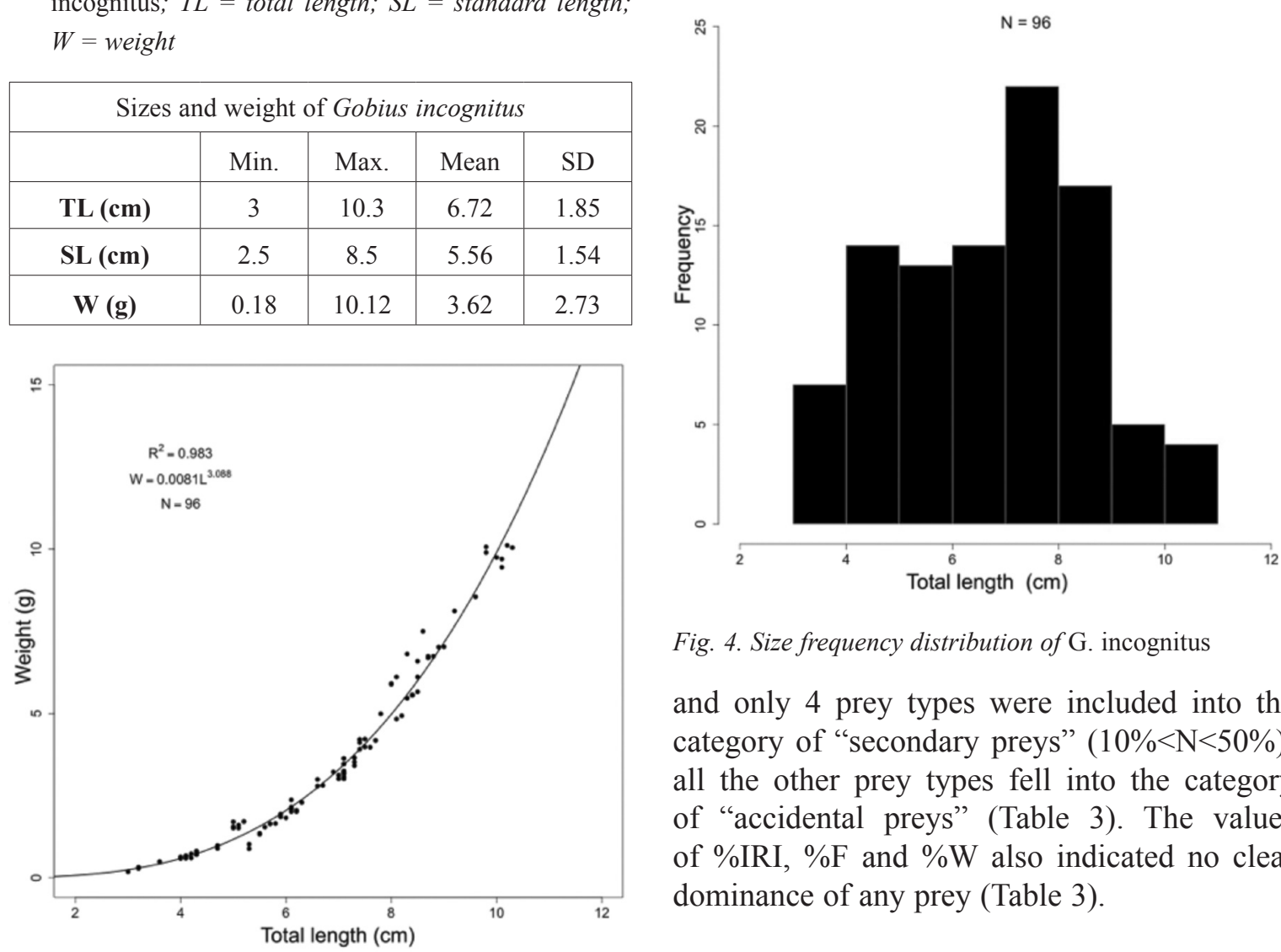

Fig. 4. Size frequency distribution of $\mathrm{G}$. incognitus

and only 4 prey types were included into the category of "secondary preys" $(10 \%<\mathrm{N}<50 \%)$; all the other prey types fell into the category of "accidental preys" (Table 3). The values of $\%$ IRI, $\% \mathrm{~F}$ and $\% \mathrm{~W}$ also indicated no clear dominance of any prey (Table 3).

Fig. 3. Length-weight relationship of $\mathrm{G}$. incognitus

Table 3. Diet composition of G. incognitus from the Ionian Sea (southeastern Sicily, central Mediterranean Sea); \%F = percentage frequency of occurrence; $\% \mathrm{~N}=$ percentage in number; $\% \mathrm{~W}=$ percentage in biomass; IRI = index of relative importance of prey items and its percentage (\%IRI). Values $>10 \%$ are in bold

\begin{tabular}{cccccc}
\hline Food items & $\mathbf{\% F}$ & $\mathbf{\% N}$ & $\mathbf{\% W}$ & $\mathbf{I R I}$ & \%IRI \\
Algae & $\mathbf{1 1 . 9 0}$ & 7.41 & $\mathbf{1 2 . 8 9}$ & 241.68 & $\mathbf{1 2 . 6 8}$ \\
Amphipoda & $\mathbf{1 3 . 1 0}$ & $\mathbf{1 3 . 3 3}$ & 2.24 & 203.93 & $\mathbf{1 0 . 7 0}$ \\
Bivalvia & 4.76 & 3.70 & 2.10 & 27.65 & 1.45 \\
Caridea & $\mathbf{1 4 . 2 9}$ & $\mathbf{1 3 . 3 3}$ & $\mathbf{1 8 . 1 9}$ & 450.29 & $\mathbf{2 3 . 6 2}$ \\
Gastropoda & 5.95 & 3.70 & $\mathbf{1 2 . 5 5}$ & 96.77 & 5.08 \\
Lumbrinereis sp. & 7.14 & 4.44 & 3.29 & 55.26 & 2.90 \\
Mysida & 8.33 & $\mathbf{1 1 . 1 1}$ & 0.21 & 94.35 & 4.95 \\
Parvicardium scriptum & 7.14 & 5.93 & 2.88 & 62.93 & 3.30 \\
Phorcus sp. & 3.57 & 2.22 & $\mathbf{1 1 . 3 7}$ & 48.53 & 2.55 \\
Pisidia sp. & 4.76 & 2.96 & 4.28 & 34.47 & 1.81 \\
Polychaeta & $\mathbf{1 1 . 9 0}$ & 8.15 & 4.28 & 147.90 & 7.76 \\
Serpulidae & 4.76 & 2.96 & 2.75 & 27.20 & 1.43 \\
Tanaidacea & $\mathbf{1 4 . 2 9}$ & $\mathbf{1 1 . 1 1}$ & 1.09 & 174.24 & 9.14 \\
Xantho sp. & 8.33 & 5.19 & $\mathbf{1 7 . 3 4}$ & 187.70 & 9.85 \\
\hline Digested & 5.95 & 4.44 & 4.55 & 53.52 & 2.81 \\
\hline
\end{tabular}




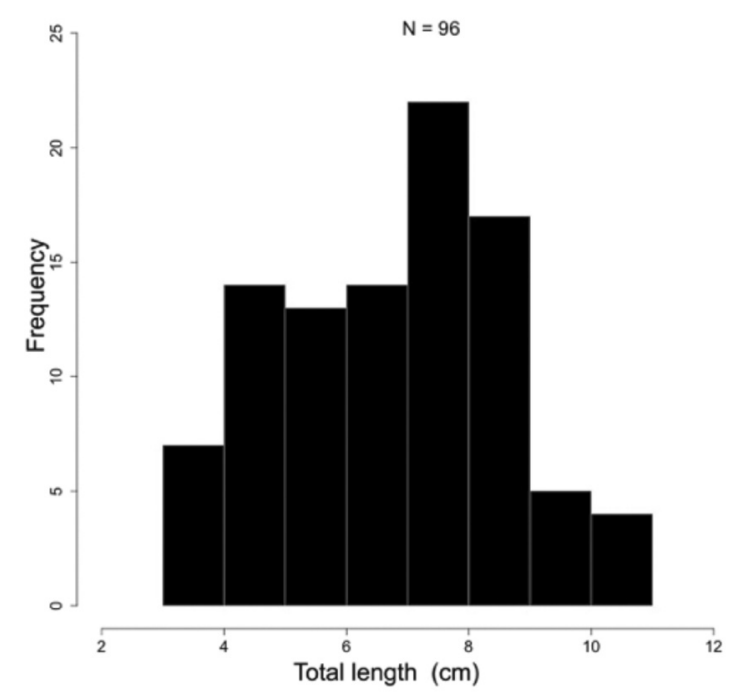

Fig. 4. Size frequency distribution of $\mathrm{G}$. incognitus

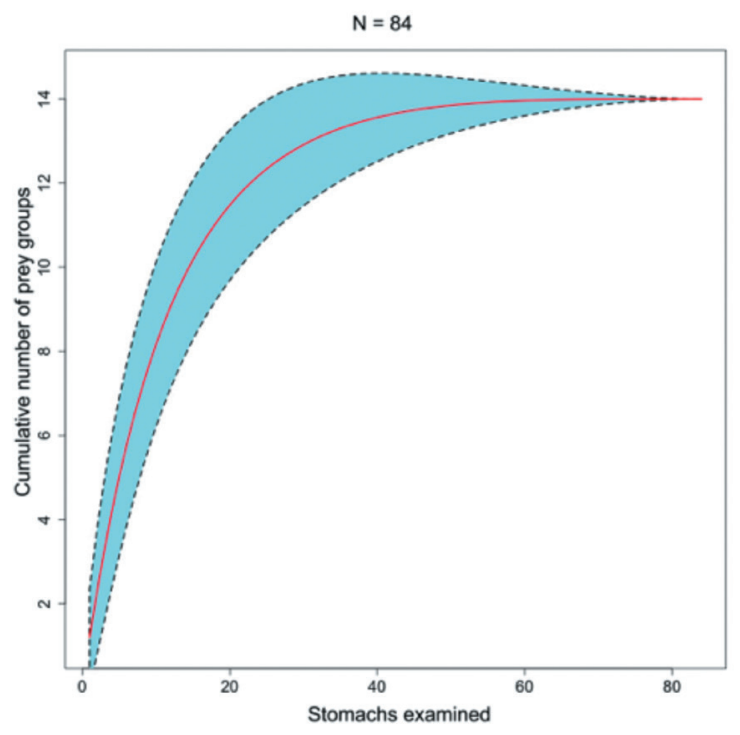

Fig. 5. Cumulative prey curve as a function of sample size for all stomachs analyzed of G. incognitus. The standard deviation (SD) is represented by black dashed lines

\section{DISCUSSION}

Gobius incognitus preferred "sand and rocks", followed by "pebbles and sand" and "rock with vegetation". In these two latter habitat types, the abundance of specimens was similar; however, in "pebbles and sand" it was slightly higher than that of "rock with vegetation". No specimens were recorded in "sand". Hence, this species definitely prefers "sand and rocks", where it can reach quite high densities (mean

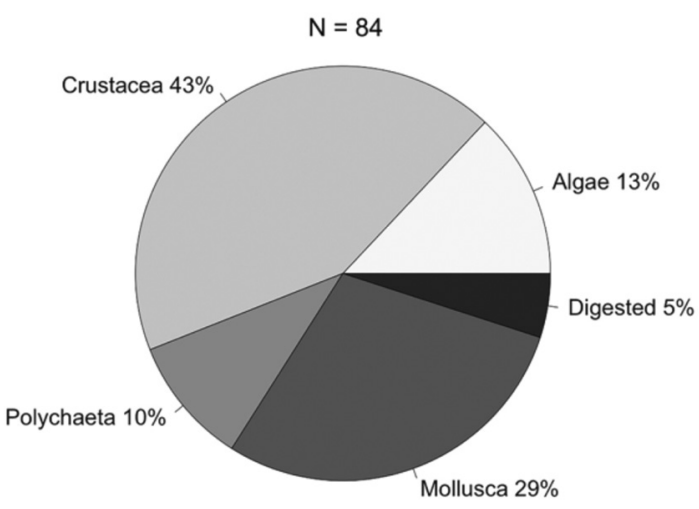

Fig. 6. Diet composition in $\% W$ of $\mathrm{G}$. incognitus for the main taxonomic groups

$=0.60 \pm 0.11$ specimens $\left./ \mathrm{m}^{2}\right)$. In this habitat, but also in "pebbles and sand", the species was usually observed on sand close to the entrance of the shelters, represented by crevices between rocks (or pebbles) on sand or by small spaces under rocks (or pebbles) on sandy bottom. The absence of the species from sandy bottoms (habitat type $=s$ ) could be due to the absence of shelters in this habitat. Indeed, when it feels threatened, it hides under rocks or pebbles, or among them. Furthermore, in "rock with vegetation", where the density of $G$. incognitus reached mean values of 0.24 specimens $/ \mathrm{m}^{2}$, the species was often found associated with A. viridis and when it felt threatened it hid among the tentacles of the sea anemone. Also, the scarcity of food resources on sandy bottom could be another factor that affects the species' distribution. However, the dominant factor that seems to directly affect the abundance of the species is the substrate nature, and in particular the presence of shelters. Hence, the presence of typical species of rocky and mixed bottoms in the diet of $G$. incognitus would simply be the consequence of habitat selection. In all cases, $G$. incognitus was by far the most common goby species in the investigated habitat types, with the exception of $P$. marmoratus that was the only goby species observed on "sand", although in low numbers. The other two species of gobies (G. cobitis and G. paganellus) recorded in $s r, p s$ and $r v$ were always observed in low numbers.

The low percentage $(14.6 \%)$ of empty stomachs (14 out of 96) indicated that $G$. 

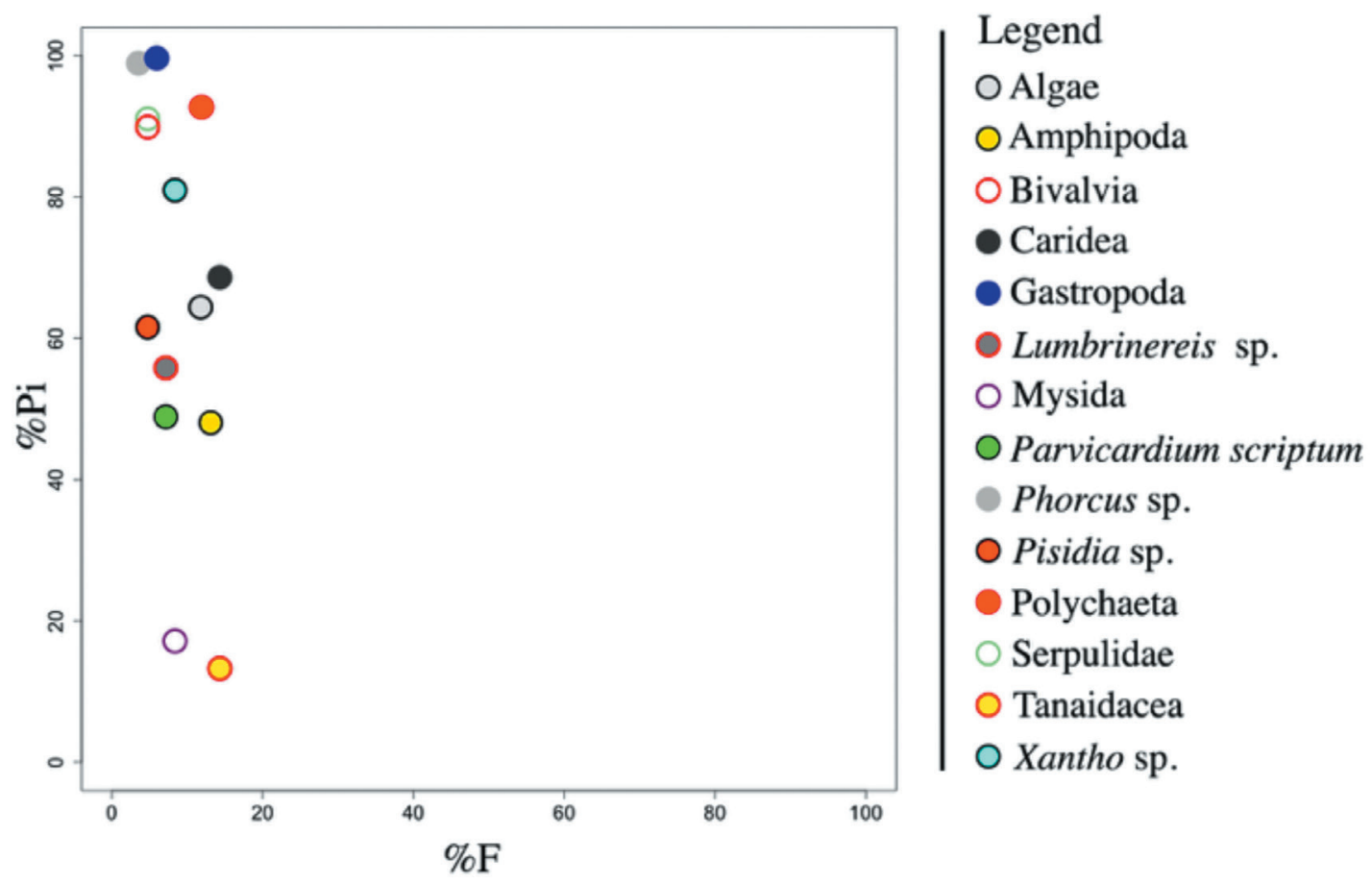

Fig. 7. Feeding strategy plot for G. incognitus

incognitus actively feeds during daylight hours. The plot of the prey-specific biomass $(\mathrm{P} i)$ and the frequency of occurrence $(\% \mathrm{~F})$ did not show a clear evidence of any prey dominance. The same was shown by the value of the Levins' index, that clearly indicated a generalist feeding behavior. However, in terms of biomass, crustaceans, followed by molluscs, were the most important food item. Amphipoda, Caridea and Tanaidacea reached the highest values in terms of frequency of occurrence $(\% \mathrm{~F})$. These data partially agree with those of PÖLZER \& PATZNER (2000), in which crustaceans were equally the most important food item, but molluscs were scarcely represented. However, considering the study of KOVAČIĆ \& ŠANDA (2016), we can't be sure to which of the two species (G. bucchichi or G. incognitus) they referred.

Most of the preys were "accidental", and only four were classified as "secondary", namely Amphipoda, Caridea, Mysida and Tanaidacea. In all cases, with the exception of Mysida, all the identified prey categories were strictly benthic. However, during visual census and sampling activities, we observed several specimens of Leptomysis sp. close to the bottom and associated with $A$. viridis. As in the case of G. incognitus, Leptomysis found probably protection from predators among (or near) the tentacles of the sea anemone (PATZNER, 2004). In all cases, this particular behavior makes them easy prey for $G$. incognitus, which can be classified as strictly benthic fish.

In other goby species of similar (Gobius roulei) and smaller size (Buenia affinis and Gobius vittatus) it was demonstrated that larger specimens feed mainly on benthic macrofauna and fish, while smaller specimens feed mainly on meiofauna (KOVAČIĆ, 2001; KOVAČIĆ, 2007; KOVAČIĆ \& LA MESA, 2008). Contrariwise, in our study, both small and large specimens of $G$. incognitus feed mainly on benthic macrofauna, whilst no fish were recorded in their stomachs. However, most of the specimens analyzed were of medium and large size. A similar situation, in which no significant difference was found between the feeding habits of juveniles and adults, was recorded for $P$. marmoratus. Furthermore, also in this latter species, crustaceans were the most important prey and no fish were recorded in the stomachs (ALTIN et al., 2015). 
There are two main alternatives for the location and capture of prey by predators (MENDELSON, 1975):

1. predators specialized in the capture of specific prey types that inhabit particular areas, where these prey are generally abundant.

2. predators adapted to particular habitat types, where they feed indiscriminately on almost any organism that occur in that habitat.

In the case of our study, the results indicated that the latter alternative best explains the feeding strategy adopted by $G$. incognitus. Indeed, data allows us to classify this species as an opportunistic feeder, mainly feeding on several species of small crustaceans, which probably are the most abundant food resources in the preferred habitat. This is in agreement with other studies in which it was demonstrated that gobies are usually generalist and opportunistic feeder, and their diet can vary widely depending on the investigated area (ZANDER \& BERG, 1984; KOVAČIĆ \& LA MESA, 2008) and season (ALTIN et al., 2015). Hence, the presence of shelters (and therefore the type of habitat), in particular those constructed under rocks (or pebbles) on sand, seems to be the most important factor affecting the presence and abundance of G. incognitus.

The results of the length-weight relationship indicated positive allometric growth, while the size frequency distribution (mean size of $6.72 \pm$ $1.85 \mathrm{~cm}$ ) indicated the presence of both juveniles and adults, though most of the specimens were of medium and large size.

\section{CONCLUSIONS}

In conclusion, we present first data on biological and ecological aspects of $G$. incognitus from specimens from the Ionian Sea. In particular, the study represents the first data on habitat preference, diet and length-weight relationship of $G$. incognitus on material with confirmed species identity. When a cryptic species is revealed within populations of long time known and well-studied species, like what happened with G. bucchichi (KOVAČIĆ \& ŠANDA, 2016), the identity of the species related to the earlier published data on species biology and ecology is usually uncertain and, therefore, those published data "lost" or, at least, questionable. That request new studies on the biology and ecology of all species originated from such taxonomic works. The later use of the data that turn to be of questionable species identity are still not addressed, and the problem is generally underestimated. Gobius incognitus is a strictly benthic species with a general preference for small benthic crustaceans. However, this species can be considered an opportunistic and generalist feeder, having no preference for any particular species. The species showed a clear preference for "mixed bottoms" (sand and rocks in particular), in which probably the complexity of habitat provides the best combination of food availability and protection against predators. Further studies are necessary to provide additional data to deepen our knowledge on the biology and ecology of this species.

\section{REFERENCES}

ABEL, E.F. 1960. Liaison facultative d'un poisson

(G. bucchichi Steindachner) et d'une anemone (Anemonia sulcata Penn) en Méditerranée. Vie Milieu, 11: 517-531.

ALTIN, A., O. OZEN, H. AYYILDIZ \& I.B. DABAN. 2015. Feeding habits of the marbled goby, Pomatoschistus marmoratus (Actinopterygii: Perciformes: Gobiidae), in the Çanakkale Strait, Northern Aegean Sea, Turkey. Acta Ichthyol. Piscat., 45(1): 95-100.

AMUNDSEN, P.A., H.-M. GABLER \& F.J. STALDVIK.
1996. A new approach to graphical analysis of feeding strategy from stomach contents datamodification of the Costello (1990) method. J. Fish Biol., 48: 607-614.

BOUCHEREAU, J.L. \& O. GUELORGET. 1999. Régime alimentaire de deux Gobiidae (Pisces; Teleostei) sympatriques Gobius bucchichi et Millerigobius macrocephalus des Bouches de Bonifacio. Cah. Biol. Mar., 403: 263-271. BROWN, S.C., J.J. BIZZARRO, G.M. CAILLIET \& D.A. EBERT. 2012. Breaking with tradition: 
redefining measures for diet description with a case study of the Aleutian skate Bathyraja aleutica (Gilbert 1869). Environ. Biol. Fishes, 95: 3-20.

CARRASSÒN, M., J. MATALLANAS \& M. CASADEVALL. 1997. Feeding strategies of deepwater morids on the western Mediterranean slope. Deep-Sea Res., 44: 1685-1699.

COMPAIRE, J.C., R. CABRERA, C. GÓMEZ-CAMA \&

M.C. SORIGUER. 2016. Trophic relationships, feeding habits and seasonal dietary changes in an intertidal rockpool fish assemblage in the Gulf of Cadiz (NE Atlantic). J. Mar. Syst., 158: 165-172.

COSTELLO, M.J. 1990. Predator feeding strategy and prey importance: a new geographical analysis. J. Fish Biol., 36: 261-263.

FRICKE, R., W.N. ESCHMEYER \& J.D. FONG. 2020. Eschmeyer's catalog of fishes: Species by family/subfamily. California Academy of Sciences, San Francisco USA. http:// researcharchive.calacademy.org/research/ ichthyology/catalog/fishcatmain.asp. Accessed on 15 June 2020.

HERLER, J. \& R.A. PATZNER. 2005. Spatial segregation of two common Gobius species (Teleostei: Gobiidae) in the northern Adriatic Sea. Mar. Ecol., 26: 121-129.

HUREAU, J.C. 1970. Biologie comparée de quelques Poissons antartiques (Nototheniidae). Bull. Inst. Océanogr. Monaco, 68(1391): 1-244.

HYSLOP, E.J. 1980. Stomach content analysis, a review of methods and their application. J. Fish Biol., 17: 411-429.

KOVAČIĆ, M. 2001. The biology of Roule's goby in the Kvarner area, northern Adriatic Sea. J. Fish. Biol., 59(4): 795-809.

KOVAČIĆ, M. 2007. Diet of Gobius vittatus (Gobiidae) in the northern Adriatic Sea. Vie Milieu, 57: 27-33.

KOVAČIĆ, M. \& A. LA MESA. 2008. Feeding ecology of the Buen's goby, Buenia affinis, in the Kvarner area (Adriatic Sea). Vie Milieu, 58(3): 277-281.

KOVAČIĆ, M., R.A. PATZNER \& U. SCHLIEWEN. 2012.

A first quantitative assessment of the ecology of cryptobenthic fishes in the Mediterranean Sea. Mar. Biol., 159: 2731-2742.

KOVAČIĆ, M. \& M.A. PIJEVAC. 2008. Habitat preferences, distribution, and abundance of Gobius vittatus (Gobiidae) in the Kverner area (northern Adriatic Sea). Vie Milieu, 58(1): 39-45.

KOVAČIĆ, M. \& R. ŠANDA. 2016. A new species of Gobius (Perciformes: Gobiidae) from the Mediterranean Sea and the redescription of Gobius bucchichi. J. Fish Biol., 88: 11041124.

KREBS, J. C. 1989. Ecological Methodology. Harper \& Row, New York, USA, 620 pp.

MENDELSON, J. 1975. Feeding relationships among species of Notropis (Pisces: Cyprinidae) in a Wisconsin stream. Ecol. Monogr., 45: 199230.

N'DA, K. 1992. Regime alimentaire du rouget de roche Mullus surmuletus (Mullidae) dans le nord du golfe de Gascogne. Cybium, 16: 159-168.

NELSON, J.S., T.C. GRANDE \& M.V.H. WILSON. 2016. Fishes of the world. $5^{\text {th }}$ ed. John Wiley and Sons, Hoboken NJ, USA, 752 pp.

NOVAKOWSKI, G.C., N.S. HAHN \& R. FUGI. 2008. Diet seasonality and food overlap of the fish assemblage in a pantanal pond. Neotrop. Ichthyol., 6(4): 567-576.

ORDINES, F., M. KOVAČIĆ, M. VIVAS, C. GARCÍARUIZ \& B. GUIJARRO. 2019. Westernmost Mediterranean records of three gobiid species (Actinopterygii: Perciformes: Gobiidae). Acta Ichthyol. Piscat., 49(3): 275-282.

PATZNER, R. 1999a. Habitat utilization and depth distribution of small cryptobenthic fishes (Blenniidae, Gobiesocidae, Gobiidae, Tripterygiidae) in Ibiza (western Mediterranean Sea). Environ. Biol. Fishes, 55: 207-2014.

PATZNER, R. 1999b. Sea urchins as a hidingplace for juvenile benthic teleosts (Gobiidae and Gobiesocidae) in the Mediterranean Sea. Cybium, 23(1): 93-97.

PATZNER, R. 2004. Associations with sea anemones in the Mediterranean: A review. Ophelia, 58(1): 1-11.

PATZNER, R. 2019. Mediterranean Gobies. http:// www.patzner.sbg.ac.at/Gobiidae/Gob_inc. html. Accessed on September 2019.

PÖLZER, W.\& R. PATZNER. 2000. Nahrungsspektrum 
und Gebiß der Anemonengrundel Gobius bucchichi (Gobiidae) im Mittelmeer. Z. Fischkunde, 5: 83-89.

R Core Team. 2019. R: a language and environment for statistical computing. Available at: http://www.R-project.org.

SASAL, P., E. FALIEX \& S. MORAND. 1996a. Parasitism of Gobius bucchichii Staindachner, 1870 (Teleostei, Gobiidae) in protected and unprotected marine environments. J. Wildl. Dis., 32(4): 607-613.

SASAL, P., E. FALIEX \& S. MORAND. 1996b. Population structure of Gobius bucchichii in a Mediterranean marine reserve and in an unprotected area. J. Fish Biol., 49: 352-356.

TIRALONGO, F. \& R. BALDACCONI. 2015. First record of the Combtooth Blenny, Microlipophrys adriaticus (Steindachner \& Kolombatovic, 1883) (Pisces, Blenniidae) for the Italian Ionian Sea. Check List, 11(3): 1646.

TIRALONGO, F., I. GIOVOS, G. MESSINA, D. TIBULLO \& B.M. LOMBARDO. 2019. First confirmed record of Pomatoschistus microps (Krøyer, 1838) (Pisces: Gobiidae) from the Ionian Sea with notes on habitat and distribution. Acta Adriat., 60(2): 199-204.

TIRALONGO, F., G. MESSINA, R. CAZZOLLA GATTI, D. TIBULLO \& B.M. LOMBARDO. 2018. Some biological aspects of juveniles of the rough ray, Raja radula Delaroche, 1809 in Eastern Sicily (central Mediterranean Sea). J. Sea Res., 142: 174-179.
TIRALONGO, F. \& A. PAGANO. 2015. On the presence of Gobius kolombatovici in the Ionian Sea. In: Crocetta et al. New Mediterranean Marine Biodiversity Records. Mediterr. Mar. Sci., 16(3): 682-702.

TIRALONGO, F., D. TIBULLO \& R. BALDACCONI. 2013. First record of Microlipophrys dalmatinus (Steindachner \& Kolombatovic, 1883), (Pisces: Blenniidae) in the Ionian Sea. In: Bilecenoglu et al. New Mediterranean Marine Biodiversity Records. Mediterr. Mar. Sci., 14(2): 463-480.

TIRALONGO, F., D. TIBULlO, M.V. BRUNDO, F. PALADINI DE MENDOZA, C. MELCHIORRI \& M. MARCELLI. 2016a. Habitat preference of combtooth blennies (Actinopterygii: Perciformes: Blenniidae) in very shallow waters of the Ionian Sea, South-Eastern Sicily, Italy. Acta Ichthyol. Piscat., 46(2): 65-75.

TIRALONGO, F., D. TIBULlO, G. VILLANI, E. MANCINI, R. BALDACCONI, M.V. BRUNDO \& M. MARCELLI. 2016b. Hypleurochilus bananensis (Poll, 1959) (Pisces, Blenniidae) in Italian seas: distribution, habitat preference and sexual dimorphism. Acta Adriat., 57(1): 125134.

ZANDER, C.D. \& J. BERG. 1984. Feeding ecology of littoral gobiid and blennioid fishes of the Banyuls area (Mediterranean Sea) II. Prey selection and size preference. Vie Milieu, 34: 149-157. 


\title{
Prvi podaci o staništu, prehrani i dužinsko-masenom odnosu vrste Gobius incognitus Kovačić \& Šanda, 2016 (Pisces: Gobiidae)
}

\author{
Francesco TIRALONGO *, Giuseppina MESSINA i Bianca Maria LOMBARDO \\ *Kontakt e-pošta: francesco.tiralongo@unict.it
}

\begin{abstract}
SAŽETAK
U ovom radu iznose se prvi podatci o biološkim i ekološkim značajkama vrste Gobius incognitus na temelju uzoraka iz Jonskog mora (središnji dio Sredozemnog mora). Posebno se ističu podatci o staništu, prehrani i dužnsko - masenom odnosu. Vrsta Gobius incognitus preferirala je „miješano dno“ (pijesak i stijene), gdje je dostigla relativno veliku brojnost. Analiza prehrane pokazala je da G. incognitus slijedi oportunistički način prehrane. Međutim, mali bentoski rakovi bili su najvažniji plijen. Srednja ukupna dužina iznosila je 6,72 \pm $1,85 \mathrm{~cm}$, a rast je bio alometrijski pozitivan.
\end{abstract}

Ključne riječi: Sredozemno more, gobidi, prehrambene navike, vizualni popis, Gobius bucchichi, preferentno stanište 
